\title{
Seat safety and female (under)representation in the U.S. Congress
}

\author{
Akhil Rajan, Alexander Kustov, Maikol Cerda, Frances Rosenbluth, Ian Shapiro \\ Yale University
}

Draft: May 17, 2021

\begin{abstract}
Women have made significant strides toward equal representation within the U.S. Congress, but their seat share has mostly increased within the Democratic - but not Republican-Party. We argue that one driver of women's underrepresentation among Republicans is the proliferation of safe seats. Because safe seats encourage ideological extremism in candidates and because women are stereotyped as more liberal than men, we expect women candidates to outperform men in safer Democratic seats but underperform men in safer Republican seats (relative to more competitive seats). Based on a new dataset linking all candidates for the U.S. House and their districts' partisan composition since 2000, we show women both enter and win elections in safer Republican (Democratic) seats at relatively lower (higher) rates than men. Our results strikingly suggest that, even conditional on running, a female Republican candidate has an overall better chance of winning in a competitive seat than in a safe Republican seat.
\end{abstract}

Keywords: Congress, Gender, Representation, Inequality, Electoral Competition

Word count: 3700 


\section{Introduction}

After a record number of women won election to the United States Congress, many commentators declared 2018 to be the "Year of the Woman." But the use of a caveat is warranted: if 2018 was the year of the woman, it must have been the year of the Democratic woman. By contrast, Republican women lost a whopping ten seats, their largest decline in the history of the United States House of Representatives. It was not until the next election cycle that Republican women were able to make significant strides of their own. By 2020, of the fourteen seats in the United States House of Representatives that Republicans managed to win back from Democrats, eleven featured Republican women. This feat was all the more striking in view of the fact that there were a mere thirteen women in the entire Republican caucus in the preceding House session. But this focus on the strength of swing seat Republican women may obscure another important finding: swing seats might be some of the only places in which most Republican women can win.

While women have made significant strides toward equal representation within the Democratic Party, their seat share of the Republican Party has only marginally increased since 1985 (see Figure 1). What accounts for this growing gap in the partisanship of women in Congress? Many studies show that, although women's representation in Congress still lags significantly behind their male counterparts, voters appear to prefer women candidates to otherwise identical male candidates, at least in experimental contexts (see Teele, Kalla, and Rosenbluth 2018). The larger pool of women candidates among Democrats (Crowder-Meyer and Lauderdale 2014) may further explain why women are comparatively underrepresented among the congressional GOP. This conventional explanation, however, cannot explain why the partisan gap in female representation has increased consistently over the past four decades without swings of corresponding magnitude or stability in the partisan gender gap of general election voters. 
Figure 1: The Trajectories of Women's Representation in the US House
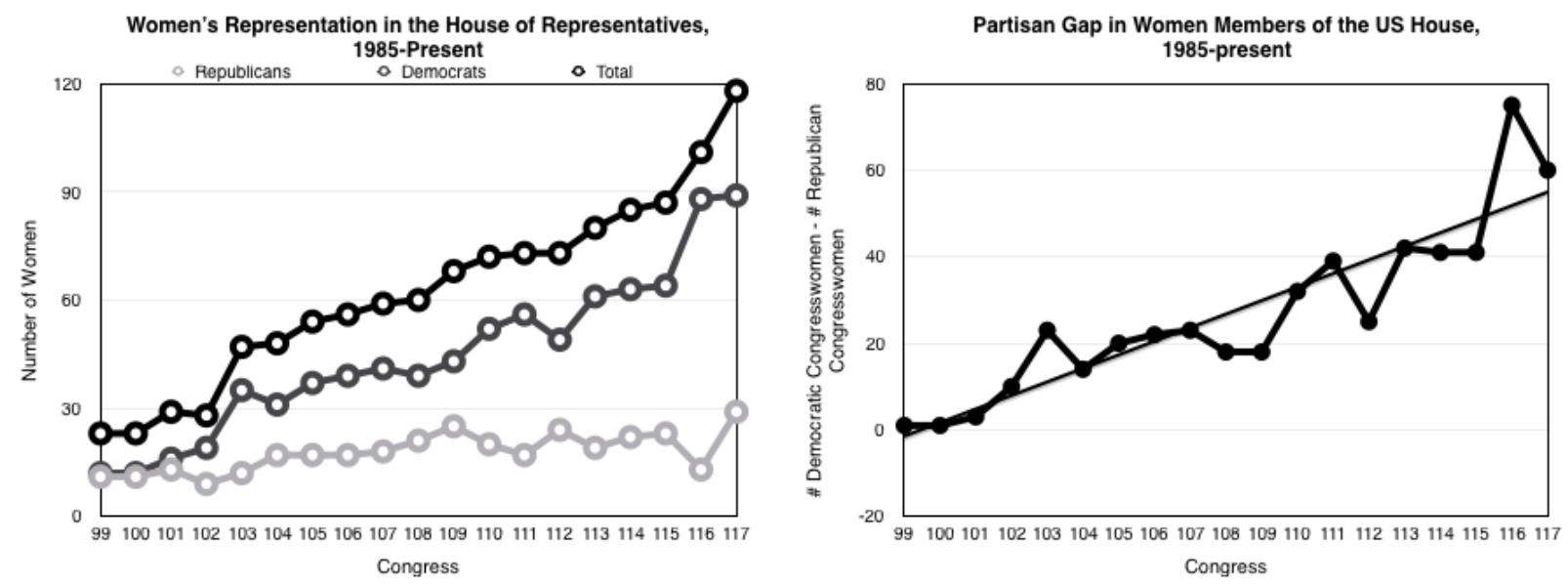

In this note, we argue that one important_yet previously overlooked-institutional driver of women's relative underrepresentation within the GOP is the recent proliferation of safe seats, seats where a political party is virtually guaranteed victory in a general election regardless of its candidate. Specifically, because safe seats encourage ideological extremism, and because women are stereotyped as more liberal than men, we expect women candidates to underperform men in safer Republican seats but outperform men in safer Democratic seats.

Based on a new dataset linking all candidates for the U.S. House and their districts' partisan composition since 2000, we show that the gender disparities in the probability of winning an election are conditioned by seat safety. According to our descriptive results, women entrants win elections at higher rates in safer Democratic seats than men across the board. At the same time, women are severely disadvantaged in the safest Republican seats.

This pattern appears to be particularly driven by gendered discrepancies in success rates at different stages of the electoral cycle. As seats get more favorable to Republicans, the gender gap in primary elections for Republican women and general elections for Democratic women increases. To that 
end, we also show that, perhaps responding to this bias, women candidates are far more likely to run in safe Democratic seats than safe Republican seats.

Finally, we demonstrate that these disparities are substantively important. For instance, our estimates suggest that a woman entering a Republican primary has a better chance of winning the seat outright in a competitive seat than in a safe seat. Moreover, our results suggest that gender biases are at their nadir across parties in competitive seats, suggesting that efforts to eliminate partisan gerrymandering may also yield more bipartisan progress toward gender parity.

Overall, our results contribute to a nascent literature on the unintentional effects of redistricting on descriptive representation, a subject that has been explored at length with regard to race but rarely with regard to gender. Our hope is that this note will stimulate further examination of the causes and consequences of preference divergence and gender representation not just between but also within American political parties.

\section{Electoral Competition and Female Representation in the U.S. Congress}

Since the 1980s, the number of Democratic women has ballooned while the number of Republican women has grown anemically. According to conventional wisdom, this gap is a result of more women running for office under the Democratic banner. While it is true that a greater proportion of Democratic candidates are women than Republican candidates, this relationship itself is arguably endogenous to women's underrepresentation. If Republican women face steeper hurdles to running for office successfully, they will be less likely to join the race in the first place. Put differently, a partisan gap in women who enter politics cannot fully explain the partisan gap in women's representation in Congress. Furthermore, little evidence supports the notion that the partisan gap in women's political allegiances has systematically grown over the past forty years, 
at least in terms of presidential voting (see Figure A1). Thus, their insights notwithstanding, these existing explanations fail to fully account for the gender gap between parties or its recent growth.

We argue instead that the growing partisan gap in female representation is also a function of declining electoral competition between parties across House districts. Specifically, our argument is rooted in two older premises established in the literature on electoral and descriptive determinants of candidate success. According to the first premise, safe seats augment the importance of primaries over general elections and thereby encourage ideological extremism among candidates (e.g., Persily 2015, Polborn and Snyder 2017). According to the second premise, female candidates are or are stereotyped as more liberal than male candidates (King and Matland 2003; Koch 2000, 20; McDermott 1997; McDermott 1998; Sanbonmatsu and Dolan 2009). ${ }^{1}$

Combining these two premises together, we hypothesize that women candidates should outperform men in Democratic safe seat primaries but underperform men in Republican safe seat primaries. Furthermore, these premises also suggest that where general election competition transpires on a non-trivial level, Democratic women should underperform Democratic men. Thus, because of primaries for Republicans and general elections for Democrats, safe Democratic seats should bolster women candidates, while safe Republican seats should hurt women candidate from the respective parties. Since neither party poses a credible threat in general elections held in safe seats of the out-party, the recent rise of safe seats among both parties can thus at least in part explain the growing partisan gap in female representation in the U.S. House.

\footnotetext{
${ }^{1}$ For the purposes of our research note, we are agnostic as to whether, or to what extent, the perceived ideological differences between female and male candidates are grounded in reality.
} 
Indeed, the number of safe U.S. House districts has risen steadily over the last decades (see Figure A2). By the 2010s, only twenty percent of Congressional districts were competitive in general elections. Many scholars have documented the vanishing of marginal seats and its other possible causes (Abramowitz, Alexander, and Gunning 2006; Ferejohn 1977; Mayhew 1974). Partisan and bipartisan gerrymandering, the advent of majority-minority districts, urbanization that creates "packed" blue cities in red states, and "partisan (self-)sorting" have all played their parts in increasing geographic polarization (Rodden 2019). Our argument here, however, is agnostic about the exact causes of rising seat safety, so long as they are largely exogenous to the female representation in Congress.

\section{Data and Methods}

To uncover the role of electoral competition between and within parties in gender representation, we use a large data set of every candidate who has filed to run for Congress in the US since 2000. In doing so, we make use of datasets by (Bonica 2019) and Cook PVI (2019).

First, we rely on Bonica (2019)—one of the largest databases of candidates for elected office and campaign finance contributions - to assemble a list of donation recipients in the U.S. House. Because this information is extracted from campaign finance records, we are also able to extract basic demographic information - including candidate gender-as well as detailed campaign finance data for these candidates. We then append data on electoral competition to this dataset to get a fuller picture of the relationship between candidates' success and their seat safety.

Our evidence on electoral competition is based on the Cook Partisan Voting Index (2019). Unlike the simple margin of victory, this index indicates how strongly a particular district leans toward the Democratic or Republican Party compared to the nation as a whole. To that end, PVIs are 
calculated by comparing a congressional district's average two-party vote share in the past two presidential elections to the national average share for those elections (i.e., the 2016 index is based on the 2012 and 2008 presidential elections). The advantage of this measure is that it indicates $e x$ ante competitiveness based on the assumed partisan composition of various districts and thus it also allows a straightforward comparison of the number of safe seats by partisanship without contaminating effects of individual candidates or election cycles.

Our main (binary) dependent variable is winning in either primary or general elections. In our main specification, we predict the probability of winning (conditional on running) using candidates' gender and their district seat safety alongside other control variables. ${ }^{2}$

Importantly, in our main results, we do not control for incumbency. Because incumbents are elected to office by the same process we wish to study in this paper, incumbency is not exogenous to the gender biases in elections. Put differently, if we were to observe that a particular gender bias in safe seats were caused by an imbalance in the number of incumbents, that imbalance in incumbents itself would be further evidence of a gender bias. Thus, we do not to include incumbency in our main results. ${ }^{3}$

\footnotetext{
${ }^{2}$ We also take a number of steps to clean the data prior to analysis. First, we remove all candidates for the 2018 election, as full general election results were still unavailable. Second, we bin all districts with PVI scores greater in magnitude than 30 to avoid biasing our estimates by a handful of hyper-safe seats.

${ }^{3}$ However, Table A6 in the appendix demonstrates that our main results are robust to the inclusion of controls for incumbency.
} 


\section{Analysis and Results}

As outlined above, we expect that the combination of extremist pressures in safe seats of both parties and the perception of women candidates as more liberal than men should drive outsized success for women candidates in safe Democratic seats and steeper hurdles in safe Republican seats. To test this empirical expectation, Table 1 includes a series of OLS regressions that estimate the impact of candidate and electoral characteristics on the probability a candidate will attain elected office. The baseline Model 1 presents results without fixed effects or clustered standard errors. Models 2 presents the same specification with additional fixed effects for both election cycle. Model 3 introduces clustered standard errors at the district-cycle level because of crosssectional correlation among candidates running in the same seat and electoral cycle. Model 4 presents the results of a specification that includes both clustered standard errors and fixed effects. Moreover, each model included candidate-level control variables for logged spending, logged PAC donations, the number of primary opponents, and seat partisanship (i.e., whether a seat leaned Republican or Democratic, to ensure that our measure of PVI was not merely serving as a proxy for the binary partisan leaning of the electorate).

In aggregate, we find strong evidence that, conditional on running for office and depending on their partisanship, female candidates can face a significant (dis)advantage compared to male candidates. But the gender differences in win rate are not constant across seats: as the PVI of a seat increases (i.e., it trends more Republican) the gender gap between female and male candidates increases. This finding suggests that, as predicted, safe Democratic seats reward women candidates, while safe Republican seats sanction them. 
Table I: Gendered Differences Between the Overall Win Rate and Seat Safety

\begin{tabular}{|c|c|c|c|c|}
\hline & \multicolumn{4}{|c|}{ Dependent variable: } \\
\hline & \multicolumn{4}{|c|}{ Probability of Winning Elected Office } \\
\hline & $(1)$ & $(2)$ & $(3)$ & (4) \\
\hline Female & $\begin{array}{c}-0.046^{* * *} \\
(0.007)\end{array}$ & $\begin{array}{c}-0.047^{* * *} \\
(0.007)\end{array}$ & $\begin{array}{c}-0.046^{* * *} \\
(0.007)\end{array}$ & $\begin{array}{c}-0.047^{* * *} \\
(0.007)\end{array}$ \\
\hline PVI & $\begin{array}{c}-0.010^{* * *} \\
(0.0004)\end{array}$ & $\begin{array}{c}-0.010^{* * *} \\
(0.0004)\end{array}$ & $\begin{array}{c}-0.010^{* * *} \\
(0.0004)\end{array}$ & $\begin{array}{c}-0.010^{* * *} \\
(0.0004)\end{array}$ \\
\hline Republican & $\begin{array}{c}0.051^{* * *} \\
(0.005)\end{array}$ & $\begin{array}{c}0.050^{* * *} \\
(0.005)\end{array}$ & $\begin{array}{c}0.051^{* * *} \\
(0.007)\end{array}$ & $\begin{array}{c}0.050^{* * *} \\
(0.007)\end{array}$ \\
\hline Female*PVI & $\begin{array}{c}-0.002^{* * *} \\
(0.0004)\end{array}$ & $\begin{array}{c}-0.002^{* * *} \\
(0.0004)\end{array}$ & $\begin{array}{c}-0.002^{* * *} \\
(0.0004)\end{array}$ & $\begin{array}{c}-0.002^{* * *} \\
(0.0004)\end{array}$ \\
\hline Republican*PVI & $\begin{array}{l}0.020^{* * *} \\
(0.0004)\end{array}$ & $\begin{array}{l}0.020^{* * *} \\
(0.0004)\end{array}$ & $\begin{array}{l}0.020^{* * *} \\
(0.0005)\end{array}$ & $\begin{array}{l}0.020^{* * *} \\
(0.0005)\end{array}$ \\
\hline Candidate Controls & Yes & Yes & Yes & Yes \\
\hline Time fixed effects & No & Yes & No & Yes \\
\hline Clustered SEs & No & No & Yes & Yes \\
\hline Observations & 15,640 & 15,640 & 15,640 & 15,640 \\
\hline Adjusted $\mathrm{R}^{2}$ & 0.583 & 0.587 & 0.583 & 0.587 \\
\hline
\end{tabular}

To provide even more illustrative evidence that the impact of safe seats helps account for the growing partisan divide in women's representation, we also plot the simple predicted probabilities of winning an election by seat safety depending on candidates' party and gender in Figure $2 .{ }^{4}$ As can be clearly seen, while Democratic safe seats are slightly more likely to elect women than men, the safest Republican seats are sharply biased toward male candidates. In particular, in the safest Republican seats, our point estimates suggest that Republican men have an almost 50 percentage

\footnotetext{
${ }^{4}$ For additional plots showing the predicted probability of winning in primary and general elections separately by party, see Figure A3. For respective tables, see Tables A2, A3, A4, and A5.
} 
point advantage over Republican women in their chances of attaining elected office, while in the safest Democratic seats, Democratic women may have an advantage of as much as 20 percentage points over men. Importantly, these gaps in electoral success between men and women virtually disappear in competitive seats.

Figure 2: Overall Predicted Probability of Winning by Seat Safety, Party and Gender
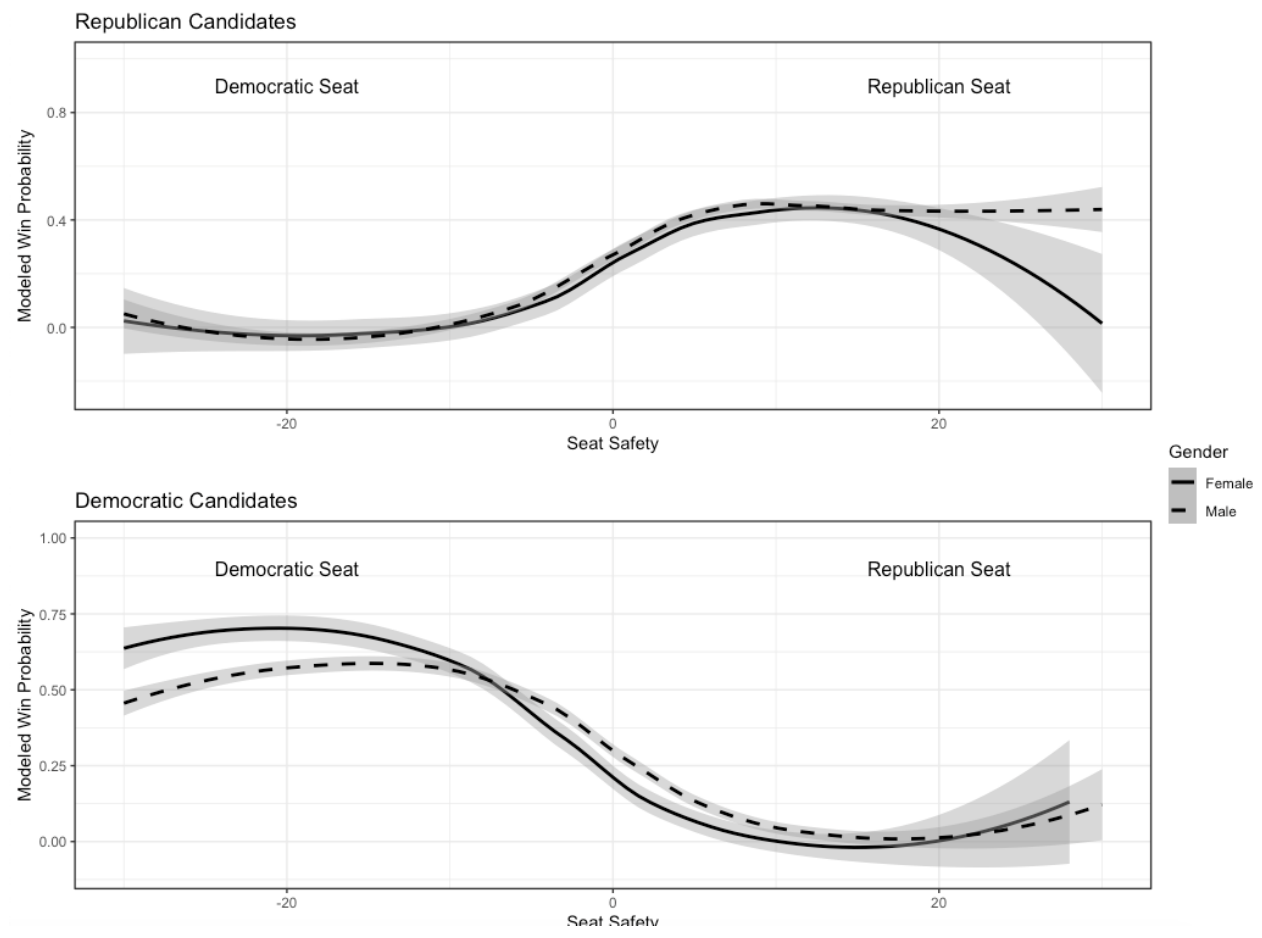

Note: Seat safety varies from safest Democratic to safest Republican districts (based on CPVI)

The sharp divergence between women's and men's outcomes in the safe seats with PVI scores greater than $\mathrm{R}+20$ may not seem terribly alarming at first blush. But in light of the proliferation of Republican safe seats (see Figure A2), 38 House districts fall into this category, comprising almost one-fifth of the overall Republican caucus in the 117th Congress. 
The evidence we have provided so far has been based on the gender-based winning probabilities conditional on running in an election. From the previous literature, however, we know that there are usually fewer female than male candidates to begin with, which is especially true in the GOP (e.g., see Crowder-Meyer and Lauderdale 2014). However, we posit that this gender gap in the supply of women candidates is also impacted by seat safety. Perhaps as a result of women's advantage in safe Democratic seats and disadvantage in safe Republican seats, we see that female candidates tend to emerge at far higher rates in safe Democratic seats than safe Republican seats (see Figure 3). Importantly, however, we also see that the partisan gap in the supply of female candidates is rather stable regardless of seat safety. Quite strikingly, this implies that—despite the longstanding partisan gap — in primaries the proportion of female candidates among Republican female candidates in safe Democratic seats is actually greater than the proportion of Democratic female candidates in safe Republican seats (and vice versa).

Figure 3: Proportion of Female Candidates in Primary Elections by Seat Safety



Note: Seat safety varies from safest Democratic to safest Republican districts (based on CPVI) 
We then also test whether this undersupply stems from a recognition of innate biases within the primary electorate. To that end, Table A2 reports the results of an OLS regression analysis on Republicans running for Congress, and their probability of winning the primary. Overall, we find significant evidence that the gender gap in the likelihood of winning in the Republican Primary increases with seat safety, as women become more disadvantaged. In other words, in line with our general argument, while Democratic women benefit from running in a safer seat for their party, Republican women are disadvantaged by seat safety in primary elections.

But even for Democratic candidates, the gender gap against women widens as seats become more favorable to Republicans (and thus more ideologically conservative). This is because Democratic women — who we expect to be perceived as more liberal — may be seen as more ideologically out of step with general election voters in moderate districts. Thus, we also report the results of a regression analysis on the probability that a Democratic primary winner wins the general election (Table A3). As anticipated, more Republican-leaning seats result in a lower chance that the woman candidate wins in the general election, compared to the male candidate. As a result, women candidates' relative under-participation in safer Republican seats may stem from a realization that their hurdles to elected office_—in both parties_-increase in safer Republican seats.

Overall, our evidence bears out the theory that women candidates are disadvantaged by Republican safe seats for several reasons. First, Republican women are severely disadvantaged by safe seat primaries: the estimated primary win rate for a Republican woman in a safe Republican seat is substantially lower than in a competitive seat. As Figure 2, shows the gender gap in win rates for Republicans goes from approximately zero in even seats to a whopping forty percentage points in $\mathrm{R}+30$ seats. Thus, though female Republican primary victors are no less likely to win in a general 
election than male ones, ${ }^{5}$ their disadvantages in safe seat primaries are so great that the estimated total probability that a women primary entrant wins a seat in Congress appears higher in competitive Republican seats than in safe ones. And second, perhaps responding to these electoral biases, Republican safe seats see a profound undersupply of women, who account for only about $1 / 16$ of primary entrants.

Given the outsized impact of the election of Donald Trump on the gender gap in voting, one might question whether our findings from pre-2018 American elections still offer valuable insights. As a descriptive matter, our analysis of PVI scores finds that in the 117th Congress, the average Republican man represents a seat that is approximately $18 \%$ more conservative than the average Republican woman, suggesting that the same patterns that lead to women's underrepresentation in safe seats still play out today.

\section{Discussion}

While women have made significant strides toward equal representation within the U.S. Congress, their seat share has mostly increased within the Democratic — but not Republican-Party. Our research note argued that one driver of women's underrepresentation among the Republicans is the proliferation of non-competitive House districts. On both sides of the aisle, safe seats have increased pressures toward extremism and increased the importance of primaries. As a result, women, who are stereotyped as more liberal, face increased difficulty compared to men in winning

\footnotetext{
${ }^{5}$ It is important to note, however, that Democratic women are conversely slightly less likely to win in general elections.
} 
primary elections in safe seats as Republicans, and slightly increased difficulty winning general elections as Democrats. This pattern has persisted even into the modern day, as cultural norms that suppressed women's representation for centuries have begun to fade, because Republican candidates are still beholden to extremely conservative primary electorates in safe seats. This is why a female Republican candidate has a better chance of winning in a competitive seat than in a safe seat.

If our results are to be believed, it is no surprise that the two most extreme members of the GOP's caucus-Marjorie Taylor-Greene and Lauren Boebert—are both women who came to power by running as extremists in high-profile primary elections. Boebert's far-right views made her a Tea Party cause célèbre, allowing her to topple a more-moderate incumbent, while Greene's embrace of conspiracy theory was widely covered in the run-up to her run-off election. The twin pressures toward extremism stemming from primaries and voter stereotypes dictate that the only successful women candidates in safe seats must extreme enough to overcome the presumptive stereotype.

This research is not without limitations. Most importantly, our descriptive analysis cannot answer the question of whether seat safety (and its recent proliferation) causally impacts gender representation in Congress. To that end, future research may benefit from identifying and exploiting the exogenous variation in electoral competition. Relatedly, our data do not allow differentiation between the possible mechanisms behind the identified relationship. The welldocumented pressure toward extremism in safe seat primaries may originate from donations, voters, or activists. Understanding the exact pressures that contribute to the dynamic we have illustrated in this paper are important to understanding the exact source of this growing gendered partisan gap. But regardless of where this pattern originates, it is important to note the striking 
degree of correspondence between seat safety and the magnitude of the gender gap. This finding suggests that further study must interrogate the ways that electoral institutions themselves have baked in women's underrepresentation, as well as the abiding importance of redistricting to even non-partisan matters of descriptive representation.

\section{References}

Abramowitz, Alan I., Brad Alexander, and Matthew Gunning. 2006. "Incumbency, Redistricting, and the Decline of Competition in U.S. House Elections." The Journal of Politics 68(1): $75-88$.

Bonica, Adam. 2019. "Database on Ideology, Money in Politics, and Elections: Public Version 2.0." https://dataverse.harvard.edu/citation?persistentId=doi:10.7910/DVN/6R1HAS (March 18, 2021).

Cook PVI. 2019. "PVI Map and District List | The Cook Political Report." https://cookpolitical.com/pvi-map-and-district-list (March 18, 2021).

Crowder-Meyer, Melody, and Benjamin E. Lauderdale. 2014. "A Partisan Gap in the Supply of Female Potential Candidates in the United States." Research \& Politics 1(1): 2053168014537230 .

Ferejohn, John A. 1977. "On the Decline of Competition in Congressional Elections." The American Political Science Review 71(1): 166-76.

King, David C., and Richard E. Matland. 2003. "Sex and the Grand Old Party: An Experimental Investigation of the Effect of Candidate Sex on Support for a Republican Candidate." American Politics Research 31(6): 595-612.

Koch, Jeffrey W. 2000. "Do Citizens Apply Gender Stereotypes to Infer Candidates' Ideological Orientations?*." Journal of Politics 62(2): 414-29.

Mayhew, David R. 1974. Congress: The Electoral Connection. Yale University Press.

McDermott, Monika L. 1997. "Voting Cues in Low-Information Elections: Candidate Gender as a Social Information Variable in Contemporary United States Elections." American Journal of Political Science 41(1): 270-83.

Mcdermott, Monika L. 1998. "Race and Gender Cues in Low-Information Elections." Political Research Quarterly 51(4): 895-918. 
Persily, Nathaniel. 2015. Solutions to Political Polarization in America. Cambridge University Press.

Polborn, Mattias K., and James M. Snyder Jr. 2017. "Party Polarization in Legislatures with Office-Motivated Candidates*." The Quarterly Journal of Economics 132(3): 1509-50.

Rodden, Jonathan A. 2019. Why Cities Lose: The Deep Roots of the Urban-Rural Political Divide. Basic Books.

Sanbonmatsu, Kira, and Kathleen Dolan. 2009. "Do Gender Stereotypes Transcend Party?" Political Research Quarterly 62(3): 485-94.

Teele, Dawn Langan, Joshua Kalla, and Frances Rosenbluth. 2018. "The Ties That Double Bind: Social Roles and Women's Underrepresentation in Politics." American Political Science Review 112(3): 525-41. 


\section{Online Appendix}

Figure A1: Gender Gap in Exit Polling

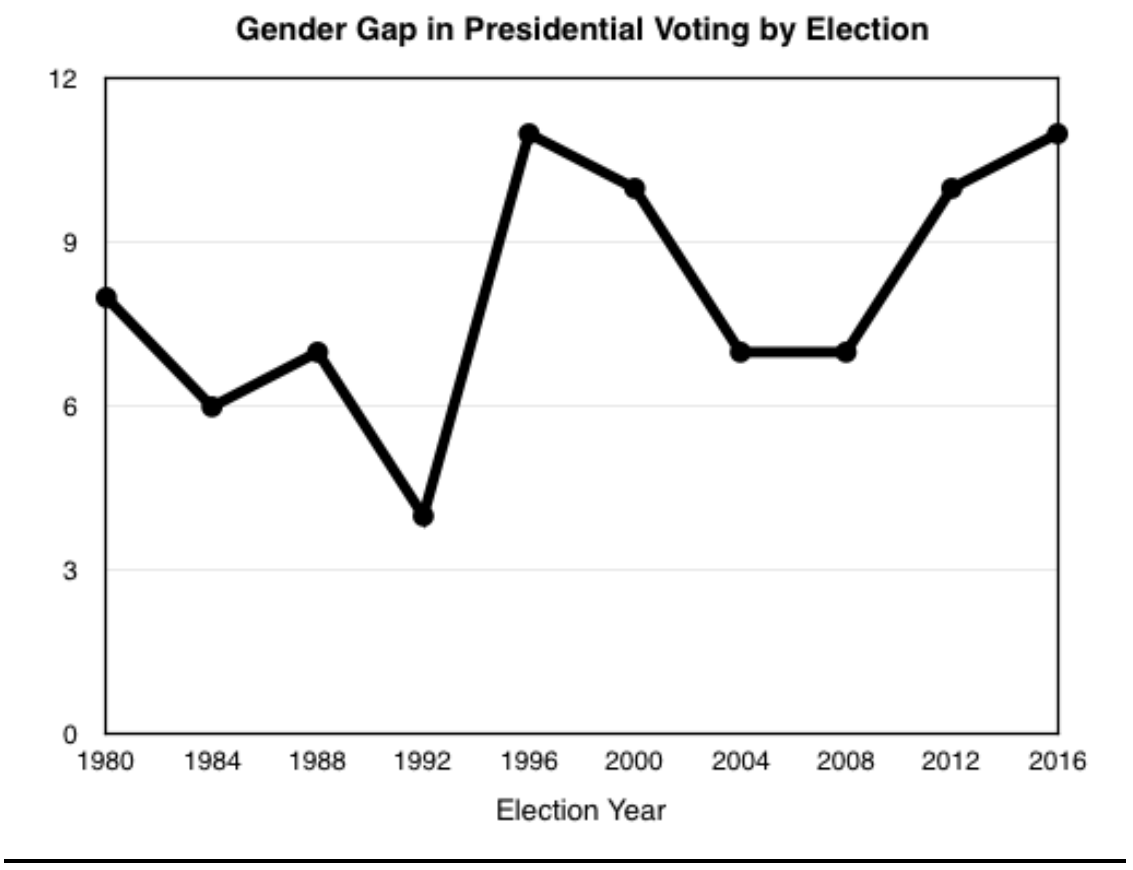


Figure A2: The Rise of Safe Seats in U.S. House Elections (1992-2020, Cook PVI)

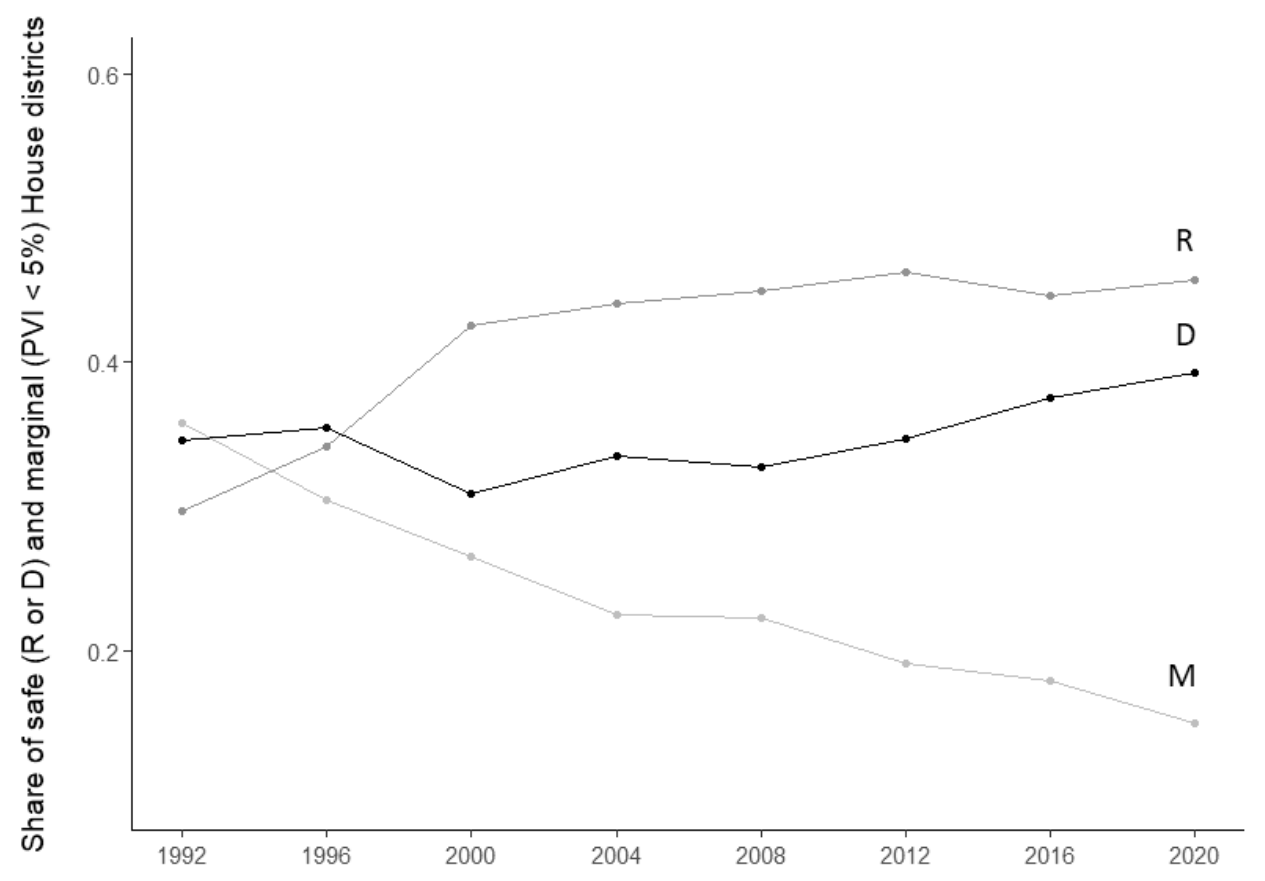


Figure A3: Predicted Probability of Winning in Primary and General Elections by Seat Safety,

\section{Party and Gender ${ }^{6}$}
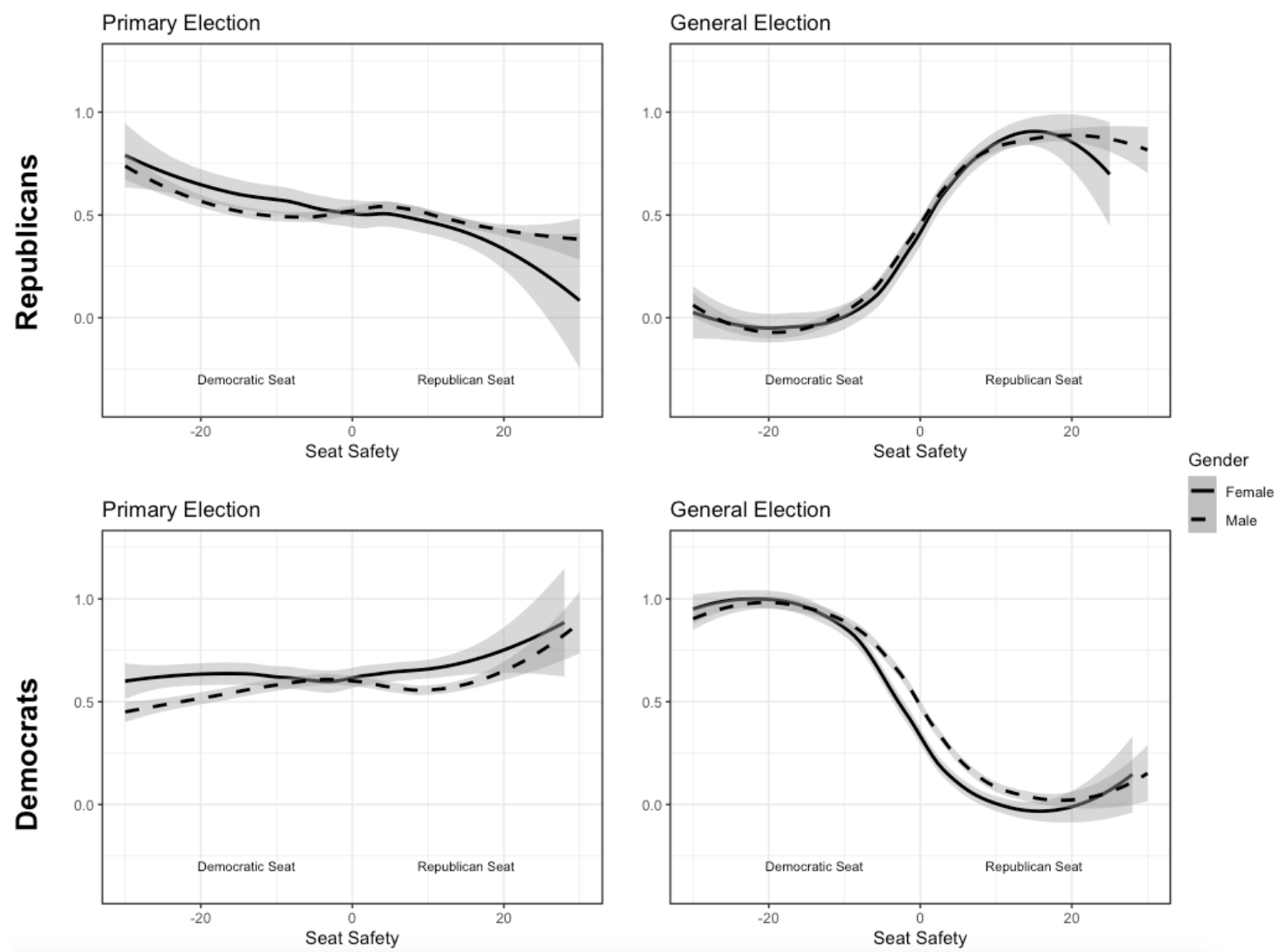

${ }^{6}$ It is important to note that each part of the figure was modeled and drawn independently. Thus, the predicted probability of winning the primary multiplied by the predicted probability of winning the general election conditional on winning the primary in a particular district may not necessarily equal the predicted probability of winning overall. When the calculations diverge, we advise heeding closest attention to the "overall" panels in Figure 2, as these models were based on the largest data set. 
Table A1: Descriptive Statistics

\begin{tabular}{lccccc}
\hline \hline Statistic & $\mathrm{N}$ & Mean & St. Dev. & Min & Max \\
\hline Female & 19,015 & 0.148 & 0.355 & 0.000 & 1.000 \\
PVI & 19,573 & 0.233 & 13.532 & $-30^{*}$ & 30 \\
Primary Vote Share & 14,070 & 0.474 & 0.408 & 0.000 & 1.000 \\
General Election Vote Share & 9,949 & 0.366 & 0.277 & 0.001 & 1.000 \\
Primary Winner & 16,897 & 0.599 & 0.490 & 0.000 & 1.000 \\
General Election Winner & 16,045 & 0.221 & 0.415 & 0.000 & 1.000 \\
Number of Primary Opponents & 19,573 & 3.399 & 2.898 & 1 & 21 \\
Number of Distinct Donors & 12,466 & $1,167.719$ & $3,099.667$ & 1.000 & $99,002.000$ \\
Total Receipts & 19,573 & $399,543.500$ & $885,212.400$ & 0.000 & $22,024,288.000$ \\
Total PAC Contributions & 19,573 & $124,910.700$ & $293,148.600$ & $-16,500$ & $3,279,747$ \\
Total Individual Contributions & 19,573 & $190,526.900$ & $433,830.000$ & $-72,816.000$ & $12,321,864.000$ \\
Total Disbursements & 19,573 & $385,728.600$ & $868,035.000$ & 0.000 & $21,197,801.000$ \\
\hline
\end{tabular}

Note: ${ }^{*}$ For ease of visualization, all entries $>30$ were binned together. 
Table A2: Predicted Probability of Winning by Seat Safety and Gender in Republican Primaries

\begin{tabular}{lcccc}
\hline \hline & \multicolumn{4}{c}{ Dependent variable: } \\
\cline { 2 - 5 } & \multicolumn{4}{c}{ Likelihood of Winning the Primary } \\
& $(1)$ & $(2)$ & $(3)$ & $(4)$ \\
\hline Female & $-0.031^{* *}$ & $-0.030^{* * *}$ & $-0.031^{* *}$ & $-0.030^{* *}$ \\
& $(0.015)$ & $(0.015)$ & $(0.014)$ & $(0.014)$ \\
& & & & \\
PVI & $-0.006^{* * *}$ & $-0.006^{* * *}$ & $-0.006^{* * *}$ & $-0.006^{* * *}$ \\
& $(0.0004)$ & $(0.001)$ & $(0.001)$ & $(0.001)$ \\
& & & & \\
Female*PVI & $-0.003^{* * *}$ & $-0.003^{* *}$ & $-0.003^{* * *}$ & $-0.003^{* *}$ \\
& $(0.001)$ & $(0.001)$ & $(0.001)$ & $(0.001)$ \\
& & & & Yes \\
Candidate Controls & Yes & Yes & Yes & Yes \\
Time fixed effects & No & Yes & No & Yes \\
Clustered SEs & No & No & Yes & 6,839 \\
Observations & 6,839 & 6,839 & 6,839 & 0.423 \\
Adjusted R ${ }^{2}$ & 0.377 & 0.423 & 0.377 & ${ }^{*} \mathrm{p}<0.1 ;{ }^{* *} \mathrm{p}<0.05 ;{ }^{* * *} \mathrm{p}<0.01$ \\
\hline \hline Note: & \multicolumn{4}{c}{}
\end{tabular}


Table A3: Predicted Probability of Winning by Seat Safety and Gender in General Elections among Democratic Candidates

\begin{tabular}{|c|c|c|c|c|}
\hline & \multicolumn{4}{|c|}{ Dependent variable: } \\
\hline & \multicolumn{4}{|c|}{ Likelihood of Winning the General Election } \\
\hline & (1) & $(2)$ & $(3)$ & (4) \\
\hline Female & $\begin{array}{c}-0.099^{* * *} \\
(0.014)\end{array}$ & $\begin{array}{c}-0.089^{* * *} \\
(0.013)\end{array}$ & $\begin{array}{c}-0.099^{* * *} \\
(0.014)\end{array}$ & $\begin{array}{c}-0.089^{* * *} \\
(0.013)\end{array}$ \\
\hline PVI & $\begin{array}{c}-0.018^{* * *} \\
(0.001)\end{array}$ & $\begin{array}{c}-0.006^{* * *} \\
(0.001)\end{array}$ & $\begin{array}{c}-0.018^{* * *} \\
(0.001)\end{array}$ & $\begin{array}{c}-0.006^{* * *} \\
(0.001)\end{array}$ \\
\hline Female*PVI & $\begin{array}{c}-0.003^{* * *} \\
(0.001)\end{array}$ & $\begin{array}{c}-0.004^{* * *} \\
(0.001)\end{array}$ & $\begin{array}{c}-0.003^{* * *} \\
(0.001)\end{array}$ & $\begin{array}{c}-0.004^{* * *} \\
(0.001)\end{array}$ \\
\hline Candidate Controls & Yes & Yes & Yes & Yes \\
\hline Time fixed effects & No & Yes & No & Yes \\
\hline Clustered SEs & No & No & Yes & Yes \\
\hline Observations & 3,291 & 3,291 & 3,291 & 3,291 \\
\hline Adjusted $\mathrm{R}^{2}$ & 0.576 & 0.627 & 0.576 & 0.627 \\
\hline
\end{tabular}

Note:

${ }^{*} \mathrm{p}<0.1 ;{ }^{* *} \mathrm{p}<0.05 ;{ }^{* * *} \mathrm{p}<0.01$ 


\begin{tabular}{lcccc}
\hline \hline & \multicolumn{4}{c}{ Dependent variable: } \\
\cline { 2 - 5 } & $(1)$ & $(2)$ & $(3)$ & $(4)$ \\
\hline Female & 0.004 & 0.012 & 0.004 & 0.012 \\
& $(0.013)$ & $(0.012)$ & $(0.013)$ & $(0.012)$ \\
& & & & \\
PVI & $0.003^{* * *}$ & $0.003^{* * *}$ & $0.003^{* * *}$ & $0.003^{* * *}$ \\
& $(0.0004)$ & $(0.001)$ & $(0.0004)$ & $(0.001)$ \\
Female*PVI & 0.0005 & 0.001 & 0.0005 & 0.001 \\
& $(0.001)$ & $(0.001)$ & $(0.001)$ & $(0.001)$ \\
\hline Fixed effects & No & Yes & No & Yes \\
Clustered SEs & No & No & Yes & Yes \\
Observations & 5,977 & 5,977 & 5,977 & 5,977 \\
Adjusted R ${ }^{2}$ & 0.399 & 0.424 & 0.399 & 0.424 \\
\hline \hline Note: & & ${ }^{*} \mathrm{p}<0.1 ;{ }^{* *} \mathrm{p}<0.05 ;{ }^{* * *} \mathrm{p}<0.01$ \\
\hline
\end{tabular}


Table A5: Predicted Probability of Winning by Seat Safety and Gender in General Elections among Republican Candidates

\begin{tabular}{lcccc}
\hline \hline & \multicolumn{4}{c}{ Dependent variable: } \\
\cline { 2 - 5 } & $(1)$ & $(2)$ & $(3)$ & $(4)$ \\
\hline Female & $-0.050^{* * *}$ & $-0.044^{* *}$ & $-0.050^{* * *}$ & $-0.044^{* *}$ \\
& $(0.019)$ & $(0.018)$ & $(0.019)$ & $(0.018)$ \\
& & & & \\
PVI & $0.014^{* * *}$ & $0.004^{* * *}$ & $0.014^{* * *}$ & $0.004^{* * *}$ \\
& $(0.001)$ & $(0.001)$ & $(0.001)$ & $(0.001)$ \\
Female:PVI & & & & \\
& 0.0002 & 0.0002 & 0.0002 & 0.0002 \\
& $(0.001)$ & $(0.001)$ & $(0.001)$ & $(0.001)$ \\
\hline Fixed effects & No & Yes & No & Yes \\
Clustered SEs & No & No & Yes & Yes \\
Observations & 3,236 & 3,236 & 3,236 & 3,236 \\
Adjusted R ${ }^{2}$ & 0.582 & 0.621 & 0.582 & 0.621 \\
\hline \hline
\end{tabular}

Note:

${ }^{*} \mathrm{p}<0.1 ;{ }^{* *} \mathrm{p}<0.05 ;{ }^{* * *} \mathrm{p}<0.01$ 
Table A6: Probability of Winning Elected Office, Controlling for Incumbency

\begin{tabular}{|c|c|c|c|c|}
\hline & \multicolumn{4}{|c|}{ Dependent variable: } \\
\hline & \multicolumn{4}{|c|}{ Probability of Winning Elected Office } \\
\hline & $(1)$ & $(2)$ & $(3)$ & (4) \\
\hline Female & $\begin{array}{c}-0.013^{* * * *} \\
(0.005)\end{array}$ & $\begin{array}{c}-0.013^{* * *} \\
(0.005)\end{array}$ & $\begin{array}{c}-0.013^{* * *} \\
(0.005)\end{array}$ & $\begin{array}{c}-0.013^{* * * *} \\
(0.005)\end{array}$ \\
\hline Incumbent & $\begin{array}{c}0.683^{* * *} \\
(0.011)\end{array}$ & $\begin{array}{c}0.681^{* * *} \\
(0.011)\end{array}$ & $\begin{array}{c}0.683^{* * *} \\
(0.012)\end{array}$ & $\begin{array}{c}0.681^{* * *} \\
(0.012)\end{array}$ \\
\hline PVI & $\begin{array}{c}-0.003^{* * * *} \\
(0.0003)\end{array}$ & $\begin{array}{c}-0.003^{* * *} \\
(0.0003)\end{array}$ & $\begin{array}{c}-0.003^{* * *} \\
(0.0003)\end{array}$ & $\begin{array}{c}-0.003^{* * * *} \\
(0.0003)\end{array}$ \\
\hline Republican & $\begin{array}{c}0.027^{* * *} \\
(0.004)\end{array}$ & $\begin{array}{c}0.026^{* * *} \\
(0.004)\end{array}$ & $\begin{array}{c}0.027^{* * * *} \\
(0.005)\end{array}$ & $\begin{array}{c}0.026^{* * *} \\
(0.005)\end{array}$ \\
\hline Female*PVI & $\begin{array}{c}-0.001^{* * *} \\
(0.0003)\end{array}$ & $\begin{array}{c}-0.001^{* * *} \\
(0.0003)\end{array}$ & $\begin{array}{c}-0.001^{* * *} \\
(0.0003)\end{array}$ & $\begin{array}{c}-0.001^{* * *} \\
(0.0003)\end{array}$ \\
\hline Republican*PVI & $\begin{array}{l}0.006^{* * * *} \\
(0.0004)\end{array}$ & $\begin{array}{l}0.006^{* * *} \\
(0.0004)\end{array}$ & $\begin{array}{l}0.006^{* * * *} \\
(0.0004)\end{array}$ & $\begin{array}{l}0.006^{* * * *} \\
(0.0004)\end{array}$ \\
\hline Candidate Controls & Yes & Yes & Yes & Yes \\
\hline Time fixed effects & No & Yes & No & Yes \\
\hline Clustered SEs & No & No & Yes & Yes \\
\hline Observations & 15,640 & 15,640 & 15,640 & 15,640 \\
\hline Adjusted $\mathrm{R}^{2}$ & 0.772 & 0.773 & 0.772 & 0.773 \\
\hline
\end{tabular}

